\title{
The ancient Mediterranean values of honour and shame as a hermeneutical procedure: A social-scientific criticism in an African perspective
}

E Mahlangu

(University of Pretoria)

\section{ABSTRACT}

The ancient Mediterranean values of honour and shame as a hermeneutical procedure: A social-scientific criticism in an African perspective

The life of modern people evolves around economics and all that goes with it, such as labour, production, consumption and possessions. These things do not only motivate many peoples' behaviour, but claim most of their energy and time. Therefore, the organising principle of life of people today is instrumental mastery - the individual's ability to control his or her environment, personal and impersonal, to attain a qualityorientated success: wealth, ownership, "good looks" proper grades, and all countable indications of success. But, in the first century Mediterranean world, economics was not the be-all and end-all. People worked primarily to conserve their status and not to gather possessions. Thus, the pivotal values of the first century Mediterranean world was honour and shame. This article looks at how social-scientific critics have attempted to show how the understanding of these values would lead to an understanding and interpretation of the New Testament. In this article the author approaches this paradigm from an African perspective. It is shown that the African interacts and transacts with the New Testament with his/her own value system in which these values are also encountered. This, therefore, makes the reading of the Bible in an African context possible.

\section{INTRODUCTION}

The nature of the theological enterprise is hermeneutical, by which is meant that biblical studies and theology is based on a search for understanding, and therefore the need for interpretation (Lombard 1995:104). Biblical theology therefore has to do with understanding the actions and utterances of the characters found throughout the pages of the Bible within one's own context. But the world, which is portrayed in the Bible, from where it also developed, is extinct - it is no longer there. Since the invention of the art of writing, it has never been possible or even neces- 
sary to put everything, which needs to be communicated, down in writing. The biblical authors are no exception. They always depended on the general and cultural knowledge of the reader. Doing all this in good faith, the New Testament writers were not conscious of the fact that they were "breaking the contract" with their future readers, who would be interested in their writings, and many of whom ideologically experience them as "the Word of God".

The world the biblical characters lived in was dramatically different from the one in which we, as the modern readers of the Bible, live today. Different from the biblical world, the European and North American worlds developed from the western Mediterranean cultures of Greece and Rome, where the Bible developed in the Eastern Mediterranean cultures of Mesopotamia, Syria, Palestine, Asia Minor and Egypt. Where the Western world is so much characterised by industrialisation and change, the biblical world was relatively static and people thought of themselves as belonging to households and their resources were limited. Today, Westerners think of themselves as individuals and their resources are renewable (See Matthew \& Benjamin 1994:10-11).

The topic of this article is "The ancient Mediterranean values of honour and shame as a hermeneutical procedure: A social-scientific criticism from an African perspective". Seeing that this subject has to do with an African perspective of honour and shame, a few observations and remarks on African philosophy, culture and world-view will be appropriate. The world-view and experience of Africans is different, as their origin is different from the Western world. They are basically not influenced by the philosophy of Plato, who questioned the phenomenological world and gave real ontological value only to the invisible. The philosophy of Descartes, who put a distance between thinking and human beings (res cogitans) and the world (res extensa) does not influence Africans. Africans think holistically, they have a collective mentality, a magical-mythical predisposition and think more concrete than abstract. The Africans' past history of political, social, economic and cultural domination by the Western nations further contributes to the unique and distinct view and experience of them and reality. Given the above scenario it stands to reason that Africa's interaction and "transaction" with the world of the Bible will differ from the West.

Malina and Neyrey (1991:14) give an impression that even if the world of Jesus had become extinct, traces of it would still be seen. They say that people visiting the Mediterranean countries today are immediately aware of a different dynamic on the streets and in the marketplaces. People in these countries seem to be more concerned with appearances. Married women typically dress in black, with kerchiefs covering their hair. Men meet in the square to smoke, drink and play

THE ANCIENT MEDITERRANEAN cards. In many places men and women do not share the same space at the same time; in fact, those who are careful observers notice that there are men's places (such as the tarven, the animal barn and the winepress) and women are found at the wells and common ovens. According to Malina and Neyrey, anthropologists describe these phenomena in terms of a value considered dominant in the Mediterranean culture - honour. The thesis in this article wishes to discuss a hermeneutical procedure through which the New Testament text could be interpreted. It is the socialscientific approach of the values of honour and shame in the ancient Mediterranean world (of Jesus). My approach is from the African. vantage point. Before we could even go any further, it might be helpful to state issues concerning the African interpretation of the text.

\section{AFRICAN BIBLICAL INTERPRETATION (HERMEN-}

\section{EUTICS)}

Countless books, articles, conference papers and conversations about Africa, Africans, Africanism and Africanness have been written and produced without a clear attempt to state who or what an African is. Generally African biblical scholars have in their minds post-colonial black Africans in their contextual theologies. However, recent remarks by Gerald West (1999:14) that "the African biblical scholarship north of the Limpopo has been strangely silent" on issues of race, class and gender, indicates that there are some differences. There are distinctions to be made when referring to an African context. Such sentiments are also raised by Dube-Shomanah (1997:11-26). Scholars north of the Limpopo, such as Justin Ukpong (1995), seem to be working from the premise that an African context is culture, ethnicity and Africanness. However, they take into cognisance Africa's political experience, although in recent years, this has not dominated their work.

On the other hand, most South African scholars are still interpreting the gospel and the text from the vantage point of liberation hermeneutics and Black theology. The major contribution of liberation, struggle, black and African theologies in South Africa cannot be denied. But one wonders whether these could not be adapted to unique and new South African (as well as African) demands and contexts. The reason that the rhetoric of colonialism and liberation (political) no longer dominates the hermeneutical procedures of northern exegetes such as Ukpong (1995) and Mugambi (1999), represents a paradigm shift. African context, perspective, hermeneutics, vantage point, in this article takes into cognisance what Africa has gone through (slavery, colonialism, apartheid, exploitation, gender inequality). But I think that African biblical scholars in South Africa should focus more on the text in the context of 
the new experiences and challenges of the new South Africa and Africa at large. Such a call to African scholars is also made by Obeng (1999).

\section{HONOUR AND SHAME IN THE ANCIENT MEDITER- RANEAN AND RESEMBLANCES IN AFRICAN CULTURE: A SOCIAL-SCIENTIFIC APPROACH}

The social-scientific criticism of the Bible should not be confused with the social description of Scripture. Scholars who work descriptionally in their approach to the Bible, attempt to explain the situational context of the text. The interest is primarily historical in character for theological relevance. It is an endeavor to analyse the early Christian world by using findings from history, archaeology, ancient literature, social theories, etc. (Scroggs 1980:164). On the other hand, social-scientific criticism of the Bible is a phase in exegesis where the analysis of the social and cultural dimensions of the text and its environmental context through the utilisation of the perspectives, theories, models, and research of the social sciences, is done. This paradigm presupposes a relationship between the text and the socio-historical environment from which it originated. I regard this as a valuable paradigm to interpret the text even in an African context. It should be pointed out that this approach is descriptive. I will approach data in the world of Jesus to describe regular patterns and generalities. The aim is not so much to explain complex exegetical phenomena, but to form a general picture of the African values (honour and shame) that will enhance understanding of the biblical text, especially in Africa.

\subsection{Honour and shame defined}

\subsubsection{Honour}

Some of the typical meanings of honour, found in dictionaries, are:

- The price or value of something

- Respect paid to someone

- Honorary office

- Dignity and status

- Honour or awards given to someone (See Mahlangu: $56 \mathrm{ff}$ ).

- The following definitions are important and insightful. It should be conceded that I ostensibly provided more than enough definitions but I thought it appropriate to enumerate this selection here because each of them adds a unique dimension. Honour can be defined as:
"The positive value of a person in his or her own eyes plus the positive appreciation of that person in the eyes of his or her social group" (Malina and Neyrey 1991:25).

"The socially approved and expected attitudes and behaviour in the areas where power, sexual status and religion intersect. It is the public claim to worth and status along with the social acknowledgement of such worth status and reputation" (Elliott 1993:130).

"Honour provides a nexus between society and their reproduction in the individual through his aspiration to personify them. As such, it implies merely a habitual preference for a given mode of conduct, but the entitlement to a certain treatment in return" (P.H-Rivers 1994:22).

"Honour is the apex of the pyramid of temporal social values and it conditions their hierarchical order. Cutting across all other social classifications it divides social beings into two fundamental categories, those endowed with honour and those deprived of it" (Peristiany 1994:10).

The above definitions of honour boil down to one thing. Each male had a sense of worth as a person, and this status had to be recognised by others. Today the life of Westerners (including developing nations under Western influence) centres around economics and all that goes with it, such as labour, production, consumption and possession. These do not only motivate many people's behaviour, but claims most of their time and energy. It is basically what people live for. Malina (1993:31) has this to say about the United States:

"In the United States, the social institution upon which most Americans focus their attention, interests, and concerns is economics. When the average US family is in difficulty, it is invariably due to the fact that the US provisioning system, the system of jobs, of goods and services production and consumption is in trouble. Thus we can fairly say, given our experience, that the focal institution of US society is economics. In this framework, the organising principle of life in this country is instrumental mastery - the individual's ability to control his or her environment, impersonal, to attain a quantity-oriented success: wealth, ownership, "good looks", proper grades, and all other countable indications of success." 
In the first century Mediterranean world, economics was not the be-all and end-all. The men worked to conserve their status and not primarily to gather possessions. Those, who tried to gather money, were suspected of doing it at the expense of the group to which they belonged. The pivotal values of the ancient Mediterranean world, the World of Jesus, were thus honour and shame.

\subsubsection{Shame}

Shame (chiefly in women) can be described as the reversal of honour. It is "contempt, loss of face, defeat, and loss of honour" (Malina, Joubert $\&$ Van der Watt 1996:8). Shame sentenced a household to "death" by placing its land for instance in jeopardy. Shamed households ate too much, were lazy, quarrelsome, selfish, and thought nothing about lying to the village assembly. They were thoughtless about their sexual relationships and disrespectful to the newborn and the dead. Their herds were mangy, and their farms run down. Shamed households did not fulfil their responsibilities to neither their own members nor to neighbors. Such households were out of place and did not function properly. What has been described thus far about shame is negative. It should be taken into consideration that could be perceived as a positive value. In this sense it refers to shame people's (in most cases women) mindfulness of their public reputation (Matthew \& Benjamin 1994:12).

\subsection{Physical expressions of honour and shame}

\subsubsection{Material possessions}

\section{[a] The world of Jesus}

Honour was expressed and displayed in various ways. First and foremost honour was measured and expressed by one's possessions, which had to be displayed. Wealth in general denoted honour - not simply the possession of wealth, but its consumption and display, for example banquets, fine cloths, weapons, houses, etcetera. For instance, in Luke 4:1-14, the author demostrates the ethics of the new community, the Church. Jesus and probably his desciples are invited to eat at the house of a prominent Pharisee. In the parable Jesus makes in this text, He says that the man who hosted the function invited the poor, crippled, the blind and the lame (V. 21). In the honourable world of conspicuous consumption, which was Jesus' world, wealthy and aristocratic people signaled their status also by appropriate clothing: "...those who wear expensive clothes and indulge in luxury are in palaces" ( $\operatorname{Lk} 7: 25,16: 12$; See also 23:11).

\section{[b] The African world}

In African societies honour is also expressed by the possessions one has, such as, money, fields, herds and property. What is even more important and what bestowed honour to a man is his wives and children - the question of children is even more critical. Having children is very important in African societies. For instance, to the Yorubas of Nigeria, a child has three names:

- The one that gives honour

- The one that covers us more than cloth

- The one that gives us the boldness to speak in a gathering

The high esteem in which children are held is reflected very much in the names given to them. For instance the Igbos of Nigeria give such names:

- Nwa ka ego

- Nwa di uto

A child is more valuable than money

- Nwa di Iche

A child is sweet

- Nwa di uko

A child is special

- Nwa bu ugwu A child gives dignity (to his/her parents)

- Nwa di nma A child is good

- Nwa bu nkasi obi A child gives consolation

\subsubsection{Body parts}

Besides possession, another area of the external display of honour is body parts. The head and face are particular loci of personal honour and respect. Servants and courtiers, for instance, honoured the king by avoiding looking them in the face, that is by deep bow. Comparably, to slap someone on the mouth, spit in their face, box their ears or strike their heads shamed them (Mt 26:67, Lk 22:63-64; Mk 15:17-20). In the Old Testament, David not only incapacitated Goliath and the Philistines with a stone (1 Sm 17:49-50), he stabbed him and cut off his head (17:51). The head has the public symbol of honour. David demonstrated his victory by ultimately shaming his opponent. Goliath's head was taken back to Jerusalem (17:54), thus, bringing it as a trophy to Saul (17:57).

In the African culture the face and head as an expression of honour is also a reality. The honour of the man and woman is seen on his/her head and face. Those who are junior to him, including women, should avoid eye contact with him as much as possible. Looking at the man in the face would constitute a serious insult. On the other hand the married woman must always cover her face in public. 
economic standing as theirs. Obviously the chief's son will marry from the royal family or a very prominent family.

\section{[ii] Choosing a wife}

This African value of honour, as far as the choice of a life partner is concerned, makes African culture carry something along in its discourse with the Bible. For instance, when Abraham was old he made an oath with his servant Eleazer to go find a wife for his son Isaac from his own relatives. He was clearly instructed not to get Isaac's prospective wife from among the daughters of the Canaanites (Gn 24:1-66). In the New Testament the kinship of believers based on their birth is also clearly articulated. According to John, believers are "born from above", "born of the Spirit". They have experienced a second birth, they have a new Father (Jn 3:1-5). Indeed, they are adopted into the family of God (Rm $9: 4,8: 15$; Eph 1:5; Gl 4:5), Now, by virtue of their birth, they belong to a new family, they are not to be equally yoked with the unbelievers, "what light has to do with darkness?" (2 Cor 6:14a).

\section{[iii] Honour ascribed by death}

Another dimension of ascribed honour in the African value system is in the area of death. The cult of ancestor veneration is the most important aspect of traditional religion, since the ancestral spirits are concerned with the everyday life of the individual and the tribe. Death ascribes honour status to a person even more than the time when he/she was alive. They have the honour of being mediators between the Supreme Being and the tribe/family. They mediate vitality force and allow it to be transferred to the tribe. They are not worshipped but venerated. Their family and the tribe thus honour them. Sacrifices, food, beer, snuff, etc. are brought and offered to them.

What is the significance of the death of Jesus in the New Testament? Although his death on the cross is described in the New Testament as his final humiliation and degradation, it represents only one side of the coin. It is his death (and resurrection), which bestowed upon Him the name that is above every other name and which also exalted Him to the right hand of God. It is due to his sacrificial death that $\mathrm{He}$ is Lord, every knee shall bow and every tongue confesses that Jesus Christ is Lord.

\subsubsection{Acquired honour and challenge-riposte}

Challenge-riposte is a sort of constant tug of war, a game of social push and shove. It is a type of interaction and social communication. Someone sends a message by means of a certain culturally recognised channel to the receiving individual, and this produces some sort of response. In the
"The positive value of a person in his or her own eyes plus the positive appreciation of that person in the eyes of his or her social group" (Malina and Neyrey 1991:25).

"The socially approved and expected attitudes and behaviour in the areas where power, sexual status and religion intersect. It is the public claim to worth and status along with the social acknowledgement of such worth status and reputation" (Elliott 1993:130).

"Honour provides a nexus between society and their reproduction in the individual through his aspiration to personify them. As such, it implies merely a habitual preference for a given mode of conduct, but the entitlement to a certain treatment in return" (P.H-Rivers 1994:22)

"Honour is the apex of the pyramid of temporal social values and it conditions their hierarchical order. Cutting across all other social classifications it divides social beings into two fundamental categories, those endowed with honour and those deprived of it" (Peristiany 1994:10).

The above definitions of honour boil down to one thing. Each male had a sense of worth as a person, and this status had to be recognised by others. Today the life of Westerners (including developing nations under Western influence) centres around economics and all that goes with it, such as labour, production, consumption and possession. These do not only motivate many people's behaviour, but claims most of their time and energy. It is basically what people live for. Malina (1993:31) has this to say about the United States:

"In the United States, the social institution upon which most Americans focus their attention, interests, and concerns is economics. When the average US family is in difficulty, it is invariably due to the fact that the US provisioning system, the system of jobs, of goods and services production and consumption is in trouble. Thus we can fairly say, given our experience, that the focal institution of US society is economics. In this framework, the organising principle of life in this country is instrumental mastery - the individual's ability to control his or her environment, impersonal, to attain a quantity-oriented success: wealth, ownership, "good looks", proper grades, and all other countable indications of success." 
In the first century Mediterranean world, economics was not the be-all and end-all. The men worked to conserve their status and not primarily to gather possessions. Those, who tried to gather money, were suspected of doing it at the expense of the group to which they belonged. The pivotal values of the ancient Mediterranean world, the World of Jesus, were thus honour and shame.

\subsubsection{Shame}

Shame (chiefly in women) can be described as the reversal of honour. It is "contempt, loss of face, defeat, and loss of honour" (Malina, Joubert \& Van der Watt 1996:8). Shame sentenced a household to "death" by placing its land for instance in jeopardy. Shamed households ate too much, were lazy, quarrelsome, selfish, and thought nothing about lying to the village assembly. They were thoughtless about their sexual relationships and disrespectful to the newborn and the dead. Their herds were mangy, and their farms run down. Shamed households did not fulfil their responsibilities to neither their own members nor to neighbors. Such households were out of place and did not function properly. What has been described thus far about shame is negative. It should be taken into consideration that could be perceived as a positive value. In this sense it refers to shame people's (in most cases women) mindfulness of their public reputation (Matthew \& Benjamin 1994:12).

\subsection{Physical expressions of honour and shame}

\subsubsection{Material possessions}

\section{[a] The world of Jesus}

Honour was expressed and displayed in various ways. First and foremost honour was measured and expressed by one's possessions, which had to be displayed. Wealth in general denoted honour - not simply the possession of wealth, but its consumption and display, for example banquets, fine cloths, weapons, houses, etcetera. For instance, in Luke $4: 1-14$, the author demostrates the ethics of the new community, the Church. Jesus and probably his desciples are invited to eat at the house of a prominent Pharisee. In the parable Jesus makes in this text, He says that the man who hosted the function invited the poor, crippled, the blind and the lame (V. 21). In the honourable world of conspicuous consumption, which was Jesus' world, wealthy and aristocratic people signaled their status also by appropriate clothing: "...those who wear expensive clothes and indulge in luxury are in palaces” (Lk 7:25, 16:12; See also 23:11). context of honour, challenge-riposte is a sort of interaction in at least three phases:

1) the challenge in terms of some action (word, deed or both) on the part of the challenger;

2) the perception of the message by both the individual to whom it is directed and the public at large; and

3) the reaction of the receiving individual and the evaluation of the reaction on the part of the public.

The challenge is a claim to enter into the social space of another. This claim could be positive or negative. The positive reason for entering the social space of another would be to gain some share into that space or gain a co-operative, mutual beneficial foothold. A negative reason would be to disadvantage and dislodge another from his social space, temporarily or permanently.

\section{[a] Jesus and the Jewish leaders}

In the Gospels the Jewish leaders, particularly the Pharisees and the Scribes, were constantly in conflict with Jesus. This was motivated by their honour status. In Matthew 12:1-9, for instance, Jesus went through the cornfields on the Sabbath. His disciples were hungry and they started to pick some ears of corn to eat. The Pharisees then made a public challenge to Jesus:

"... Look your disciples are doing what is unlawful on the Sabbath" $(12: 2 b)$.

Jesus had to publicly defend his honour:

"haven't you read what David did when he and his companions were hungry? He entered the house of God, and he and his companions ate the consecrated bread which was not lawful for them to do, but only for the priests" (12:3-4).

Jesus did not only demonstrate his profound knowledge of the Scriptures, but that $\mathrm{He}$ was the Messiah.

"For the Son of Man is the Lord of the Sabbath" (12:8).

Jesus, therefore successfully defended his honour.

ISSN 1609-9982 = VERBUM ET ECCLESIA Jrg 22 (1) 2001 


\section{[b] Paul and the Corinthians}

Another example in the New Testament is the Christians' honour status by virtue of their relationship with Christ and the Father. In the letters to the Corinthians, Paul demonstrates how this honour ought to be defended. The setting and background of 1 and 2 Corinthians lay a foundation for the pursuit of honour status in this city and the congregation. Factionalism in this church (1 Cor 1:12) appears to have roots in this agnostic environment. It was based on selecting and promoting a favorite orator among what was perceived to be rival orators. Dio Chrysostom remembers rivalries between orators in Corinth as being rather fierce, portraying a picture of the intense divisions which could arise between followers of different orators concerning who was the best. Paul refused to receive patronage, and enhanced the "honour" of any of the elites within the congregation. This was a stumbling block to their relationship. The partisanship, (1 Cor 1-4), therefore, belongs to this cultural competition for honour based on collecting illustrious clients, comparing one's own sophists with the sophists of the rival households or groups of followers in an effort to claim honour for oneself through one's own sophist.

Paul's dealing with his opponents in Corinth is also underlined by this value of honour. A rival Jewish-Hellenistic mission had made its way to Corinth, exploiting the Corinthians' enslavement to society's norms in order to demonstrate its superiority over Paul. These rivals play into the image of the orator who has honour, power, spiritual gifts, rhetorical skills and good references and who could accept patronage. The fact that the Corinthians yielded to such a "power play" demonstrates their embeddedness in the norms of the majority culture (honour and shame). A term, which could refer to many of Paul's concerns in Corinth, is "boasting". Its frequent appearance suggests that a primary goal of the letters is to relieve the Corinthians from this confusion about honour.

Paul addresses the issue of how the believers are to redefine their own honour on a basis other than competition in endowments recognised by the majority or dominant culture. Paul contrasts the natural endowments of the majority of believers with the honour they had received from God, argueing that, indeed, in the world's estimation the Christians had little or no honour.

\section{[c] Satan tempts Jesus}

A more classic illustration of challenge-riposte is between Jesus and Satan in Luke 4:1-13 (See also Mt 4:1-11 and Mk 1:13). At the beginning of his Gospel Luke introduces Jesus as the Son of God. This should be understood against the background of the first century Mediterranean world. In publicly acknowledging a boy to be his son, that is a member of his genealogical tree, a father not only accepted responsibility for him and made him his heir, he determined his status (honour) in the community as well.

It is noteworthy that Luke narrates the challenge-riposte of Satan to Jesus after he recorded Jesus' genealogy. A number of commentators have seen the genealogy in Luke awkwardly placed or even argue that it has minimal relation to what follows (Fitzmyer 1981:98). When one considers the social functions of genealogies in antiquity, seems to be perfectly placed. Another fact worth noting is Luke's explanation of Jesus' birth story. He tells a birth story designed to show that the power of God has been active from the beginning in such a way as to alter the apparent genealogy of Jesus (2:1-38). He narrates the obligatory (in Hellenistic biography) single childhood event portraying the character of the man (2:41-52; Malina 1990:54-64). He describes in an event of bestowing honour, God, who has the power to do so, has claimed paternity named the child publicly ritualised his fictive status (3:21-22, Gordon 1977:101).

The challenge-riposte drama occurs and commences in which Luke's honour claim for Jesus is part of the test. Note how Satan frames the challenge, "if you are the Son of God..." Precisely that has been claimed and precisely that is what has been tested. It should also be noted how Jesus responds. He does not answer in his own words, as if honour derives from what $\mathrm{He}$ is in Himself. To do that would be to grasp honour above that of his own Father and turn honour into dishonour. Jesus responds like a loyal Middle-Eastern son would always answer. He offers the words of his true Father in Deuteronomy and by such laudable behaviour He gains honour as virtue. Jesus wins that round and defeats the devil.

In the second challenge Satan asks Jesus to worship and bow down to him. Hence, the devil makes the audacious claim of being God's broker, saying that both the kingdoms of this world and the right to dispose of their resources in whatever manner he wishes to, have been given to him. He introduces a counter claim, which Luke makes only for Jesus. Jesus demonstrates that a true and honourable client would never switch patrons in this way or rather try to serve two masters at the same time. "Worship the Lord your God and serve Him only..." (4:8; Deut $6: 13)$. In the third test, even if Satan uses Jesus' weapon of quoting Scripture (Ps 91:11-12), he does not succeed. Jesus has thus defended his honour status. With the final note of satisfaction and relief, Luke tells us that Satan slicks off to await an opportune moment to strike again. Since a private challenge-riposte would gain nothing, Luke allows the reader to be the confirming public such an event requires. It should further be

ISSN 1609-9982 = VERBUM ET ECCLESIA Jrg 22 (1) 2001 
noted that it is not only Jesus who is being tested in this story. It is also the assertion that it is God who is the Father who bestows honour. It is thus with the Word of God, offered in riposte, that the devil's challenge is defeated.

\section{[b] Acquired honour in Africa}

Although at a higher level of abstraction, in the African traditional culture and value system, the challenge-riposte game is an ongoing thing. This will be demonstrated in the area of initiation rites and marriage.

\section{[i] Initiation rites}

The teenage boy or girl has to enhance his/her honour status, which through birth has been endowed on them as potential man and woman. It is through the initiation school and marriage that this is done. Birth has introduced them to the cooperate community. But is just an introduction. They remain passive and have still a long way to go. The uninitiated youth thus form a community of their own which they enact much of the life of adult members of the community. As a group, the adult members of the society look down upon them. They are considered useless individuals and they form a lawless gang whose actions fall largely outside the pattern of the tribal law.

The boy and girl must challenge-riposte the adult community and outgrow childhood and enter, both physically, causally and religiously; the adult community. This is also a change from passive to active membership in the community. The candidates in the initiation school receive instruction and training in the laws, customs of the tribe and matters pertaining to adulthood. The school is greatly enveloped in secrecy and mystery. Those who have never been to the school should never have access to what is taking place. Those who disobey the orders at the school or are found neglecting their prescribed duties are severely punished, and in some cultures even killed. The candidates are exposed to adverse conditions such as washing with cold water in winter and hunting animals for food.

Upon completion of their course, the candidates return home amidst feasting and merry-making in celebration of their newfound status as men or women. Besides the physical drama, which the initiation rites have, the occasion has also a symbolical meaning. They have challenged the adverse conditions imposed upon them by the traditions and customs of the tribe and they have won. They are thus ritually introduced to the art of communal living.

\section{[ii] Marriage}

Another rite of passage in which the young man or woman saliently defends his/her potential honour status is in the area of marriage. The African marriage, more like the Western practice, is a contract or association between two persons for mutual support and furtherance of the human race and rearing children. But in Africa marriage has a wider aspect of an alliance between groups of kin. Any marriage is a matter of interest not only of the "family unit" but also to a wider circle of relatives, particularly the members of the lineage of each. A man who is not married is regarded still as boy irrespective of his age. He is excluded from all family matters and the tribal council. He is without honour. $\mathrm{He}$ further brings shame to the members of his household. To further enhance his honour status it is common for men in Africa to practice polygyny. To have more than one wife and many children is thus regarded as honourable. One of a young woman's ambitions is to get married. A spinster who has passed a marrying age carries with her a negative stigma of not being married. Her family shares in the shame of her singleness. The same was true in Judaic culture. Hannah (Sm 1:7) who was barren was provoked by her rival Peninah who had children by her husband Elkanah.

\section{CONCLUSION}

1 This article discussed the conceptual framework of the ancient Mediterranean world of honour and shame. This aspect of the world of Jesus has been brought to the attention of the modern readers of the Bible. It was demonstrated that most social interactions of that world were undergirded by these values. We have thus familiarised ourselves to the fact that the endless conflict between Jesus and the Jewish authorities, which culminated in his death, was due to their honour status. The perspective of honour and shame helps us to appreciate, examine and understand more accurately the positive as well as the negative aspects of the life of Jesus and the others. Jesus was ever in the public eye, the proper place for an honourable male in society. Every social interaction in which he was engaged in was a potential challenge. The knowledge of honour and shame ethic, is thus essential to biblical hermeneutics.

It has also been demonstrated throughout this article that modern Africans readers of the Bible do not come and read it neutrally. Besides their distinctive experiences of reality, both religio-culturally and sociopolitically, the particular questions that such experiences generate, Africans have a range of hermeneutics strategies for interpreting the biblical texts. It has thus portrayed in this article that the African view of honour and shame could be an interpretative tool which both the African ordinary reader of the biblical text could employ. The need of such a para-

ISSN 1609-9982 = VERBUM ET ECCLESIA Jrg 22 (1) 2001 
digm is strongly felt in modern times. Charles Kraft (1987:12) is right when he says that it is imperative to develop models of reading the Bible more effectively in a multicultural world. It is therefore pertinent to interpret the Bible in a way that would reflect the view-points and life concerns of the African believers. The Bible is life orientated and should therefore be read in this way.

In conclusion, the social-scientific approach from an African perspective takes the present context of the reader seriously - the African cultural heritage (value system). Secondly, this paradigm enables the African reader to enter into dialogue with the biblical world of the New Testament. Due to various points of resemblance between the African and the first century Mediterranean cultures, it is indeed possible to approach the Bible optimistically.

\section{Consulted literature}

Breutz, P L 1991. The history of the Batswana of Bophuthatswana: A handbook of a survey of the tribes of the Batswana, $S$ Ndebele, Qwaqwa and Botswana. Ramsgate: Breutz Press.

Crafford, D 1996. "Traditional religions in Africa" in Van der Merwe \& D Crafford (eds), Religious Studies and the traditional religions in Africa. Pretoria: University of Pretoria.

De Silva, D A 1998. "Let the one who claims honour establish that claim in the Lord: Honour discourse in the Corinthian correspondence." BTB 28, 61-74.

Dube-Shommah, M 1997. "Towards a post-colonial feminist interpretation of the Bible." Semeia 78, 11-26.

Elliot, J H 1993. What is social-scientific criticism of the New Testament. Minneapolis: Fortress.

Fitzmeyer, J A 1981. The Gospel according to Luke - (1. IIX), (The Anchor Bible). New York: Doubleday, 28.

Gordon, C H 1977. "Paternity at Two Levels." JBL 96, 96-135.

Hanson, K C 1994. "How Honorable! How Shameful! A cultural analysis of Matthew's Makarisms and Reproaches", in Matthew \& Benjamin.

Kabwegyere, T 1977. "Determinants of fertility: A discussion of change in the family among the Akamba of Kenya" in Caldwell, J (ed) The persistence of high fertility, 206-240, Canberra: Australian National University.

Kraft, C H 1987. Christianity in culture: A study in dynamic Biblical theologizing in Cross-cultural Perspective. Maryknoll: Orbis.

Lombard, C 1995. "The study of religion in independent Namibia." Scriptura 53, $97-124$

Mahlangu, E 1999. The family (reality and imagery) as a hermeneutical procedure for interpreting the gospels within the socio-cultural context of the ancient Mediterranean world: An African socio-descriptive approach. Pretoria: Unpublished PhD thesis: University of Pretoria.

Malina \& R L Rohrbaugh 1998. Social Science Commentary on the synoptic gospels. Minneapolis: Fortress Press.

Malina 1990. "Mary- Mediterranean Woman: Mother and Son." BTB 20, 54-64.
Malina, 1993. The New Testament world: Insights from cultural anthropology. Louisville: John knox.

Malina, B J \& J H Neyrey 1991. "Honour and shame in Luke-Acts: Pivotal values of the Mediterranean world" in Neyrey, J H (ed), The social world of Luke-Acts. Peaboy: Hendrikson Publishers.

Malina J B, Joubert S J \& Van der Watt J G, 1996. A Time travel to the world of Jesus. Halfway House: Orion.

Masenya, M J 1994. "Freedom in bondage: Black feminist hermeneutics." Journal of Black theology in South Africa 8, 35-48.

Matthew, V H \& D C Benjamin 1994. "Introduction: Social Sciences and Biblical Studies" in Matthew, V H, An Experimental Journal for biblical criticism Honour and shame in the world of the Bible, 10-11. Atlanta: Scholars Press,

Mazrui, A A 1980. The African condition: A politicaldiagnosis. London: Heineman.

Monnig, H O 1967. The Pedi. Pretoria: Van Schaik

Mugambi, J N K 1999. An Approach to Biblical Hermeneutics. Pretoria: Unpublished Paper: Post-SNTS Conference.

Neyrey, J H 1991. Despising the shame of the cross: Honour and shame in the Johannine Passion narrative. Peaboy: Hendrikson Publishers.

Obeng, E A 1999. Emerging concerns of biblical scholarship in Ghana, Pretoria: Unpublished Paper: Post-SNTS Conference.

Okure, T 1999. Covenated with life. Invitation to African women's hermeneutical concerns. Pretoria: Unpublished Paper: Post-SNTS Conference.

Oosthuizen, G C 1991. "The place of traditional religion in contemporary South Africa" in Olupona, J K (ed), African traditional religions in Contemporary society. New York: Paragon House.

Peristianity, J G 1994. Honour and shame: The values of Mediterranean society. London: Weidenfeld and Nicolson.

Pitts-Rivers, J 1994. "Honour and shame status" in Matthew and Benjamin

Rohrbaugh, R L 1995. "Legitimating Sonship - "A test of honour" in Esler, P F (ed), Modelling early Christianity: Social-scientific studies of the New Testament in its context. New York: Routledge.

Scroggs, R 1980. The Sociological Interpretation of the New Testament: The present State of Research. NTS 26, 164-179.

Sundermeier, $\mathrm{T}$ 1999. The individual and community in African traditional religions. Picataway: Transaction Publishers.

Temples, J 1959. Bantu Philosophy. Paris: Presence Africaine.

Tienou, T 1990. The right to difference: The common roots of African theology and African philosophy. AJET 9

Uka, E M 1985. The African family and issues of fertility. ATJ 20

Van Staden, $p$ 1990. Compassion - The essence of life: A social-scientific study of the religious symbolic universe reflected in the ideology/ theology of Luke. Pretoria: Unplished DD dissertation - University of Pretoria

West, G O 1999. Mapping African biblical interpretation. Pretoria: Unpublished Paper: Post-SNTS Conference. 